\title{
Potencial de biodegradação de microcistinas por microrganismos
}

Página 185, onde se lê:

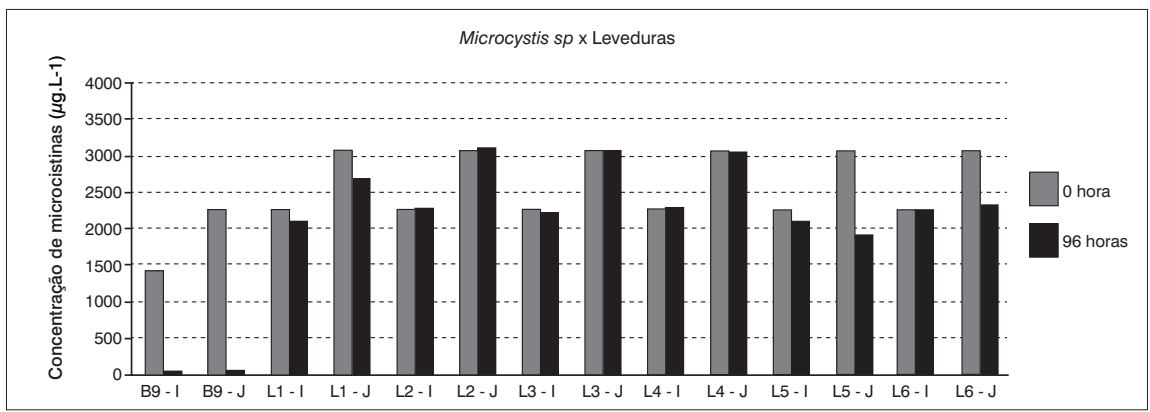

Figura 2 - Degradação de microcistinas pela bactéria B9 e seis cepas de leveduras utilizando extrato de Microcystis sp contendo microcistinas.

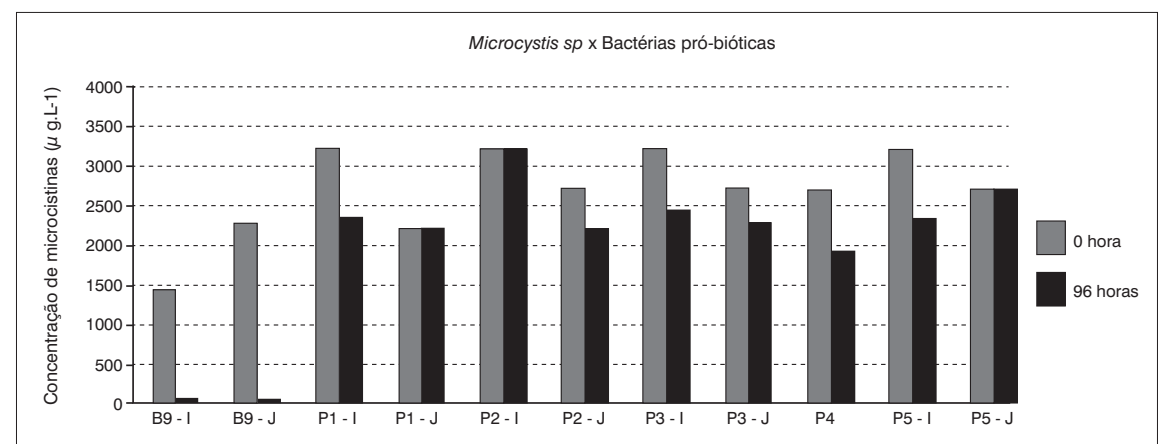

Figura 3 - Degradação de microcistinas pela bactéria B9, quatro cepas de bactérias probióticas e kefir utilizando extrato de Microcystis sp contendo microcistinas.

Leia-se:

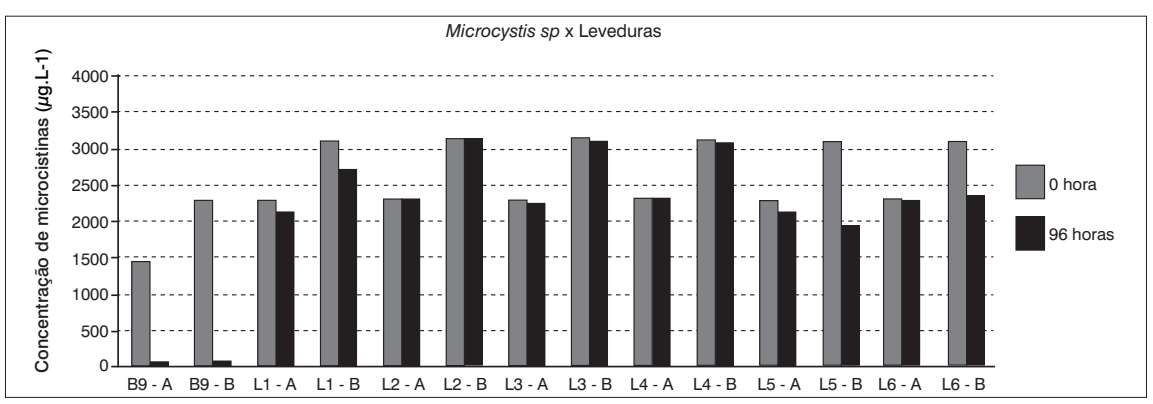

Figura 2 - Degradação de microcistinas pela bactéria B9 e seis cepas de leveduras utilizando extrato de Microcystis sp contendo microcistinas.

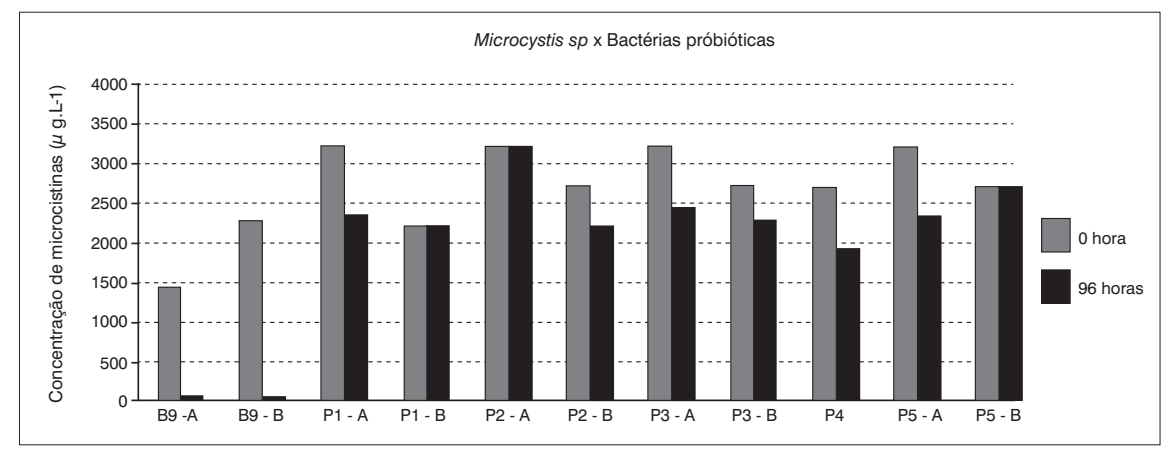

Figura 3 - Degradação de microcistinas pela bactéria B9, quatro cepas de bactérias probióticas e kefir utilizando extrato de Microcystis sp contendo microcistinas. 